\title{
TOWARDS TECHNOLOGICAL AWARENESS AND WISDOM
}

\author{
R.J. van Wyk ${ }^{1 * \#}$
}

\section{ARTICLE INFO}

\begin{tabular}{ll}
$\begin{array}{l}\text { Article details } \\
\text { Submitted by authors }\end{array}$ & 26 Oct 2019 \\
$\begin{array}{l}\text { Accepted for publication } \\
\text { Available online }\end{array}$ & 14 Dec 2020 \\
\hline & \\
$\begin{array}{l}\text { Contact details } \\
\text { * Corresponding author }\end{array}$ \\
$\quad$ corne@sun.ac.za [editor] \\
\# $\quad$ Published posthumously
\end{tabular}

Author affiliations

1 Department of Industrial Engineering, Stellenbosch University, South Africa

ORCID® identifiers

R.J. van Wyk

$\mathrm{N} / \mathrm{A}^{\#}$

DOI

http://dx.doi.org/10.7166/31-4-2274
ABSTRACT

This article aims to enhance technology foresight by contributing to technological awareness and wisdom. It is based on an understanding of the fundamental nature of technology, and requires an overarching view. This needs at least three constituents: (1) a universal definition of technology; (2) a central organising framework; and (3) a methodology for measuring technological advance at the national level. The article then addresses these constituents. It examines the status of each and projects what needs to be done.

\section{OPSOMMING}

Die doel van hierdie artikel is om tegnologiese versiendheid te verbeter. Om hierdie doel te bereik verg ' $n$ bydrae tot tegnologiese bewustheid en wysheid. Dit, op sy beurt, steun op 'n begrip van die fundamentele aard van tegnologie. 'n Oorkoepelende oorsig is nodig. Drie elemente is ter sprake: (1) 'n algemeen aanvaarde definisie van tegnologie; (2) 'n sentrale organisatoriese raamwerk; en (3) 'n metodologie om die trefkrag van tegnologie op die nasionale vlak te meet. Die artikel spreek hierdie elemente aan. Dit ondersoek die status van elk en spel uit wat gedoen moet word.

\section{INTRODUCTION}

This article is based on the personal experiences of the author in the field of technology foresight. This experience has involved professional consultation and teaching executive and graduate education.

Professional consultation covered endeavours by organisations to identify strategic opportunities by anticipating emerging technologies. About twenty corporations and national research establishments were involved. This is an activity that is hardly reported in the academic literature. Most organisations wish to maintain confidentiality, and consultants have to agree to non-disclosure agreements.

A typical endeavour follows a three-step process: (1) explore the evolving technological landscape; (2) identify technology landmarks; and (3) deploy key technologies. This sounds simple, but it is not easy. Of the twenty endeavours dealt with, four had highly successful outcomes, six yielded mediocre results, and ten failed. Why is this so?

The problem lies with Steps 1 and 2. Executive teams participating in the exercise had no shared theoretical structure available to help them form an overarching view of technology. True, they were generally au fait with the conventional, pluralistic view. The problem could be likened to a jigsaw puzzle in which the assemblers had all the necessary pieces on hand, but no knowledge of how to combine them into an integrated picture. Without an overarching view, policy-makers had little sense of the technological awareness and wisdom required for astute foresight.

To what extent is this shortcoming recognised professionally?

A strong theoretical awareness was evidenced by Farrell [1], writing in 1993. The opening sentence in a key article stated: "Technology is in need of a unifying perspective to aid in its comprehension". 
Nine years later, the National Academy of Engineering (NAE) voiced an urgent call to action. "It seems that the faster we embrace new technologies, the less we're able to understand them. What is the long-term effect of this galloping technological revolution? In today's new world, it is nothing less than a matter of responsible citizenship to grasp the nature and implications of technology" (emphasis added) [2]. With this call to action, the NAE focused on the need for widespread technological awareness and wisdom.

Progress in meeting this need has been slow. In 2009, seven years after the call to action, Arthur [3] commented: "But we have no agreement on what the word 'technology' means, no overall theory of how technologies come into being, no deep understanding of what innovation consists of, and no theory of evolution for technology. Missing is a set of overall principles that would give the subject a logical structure, the sort of structure that would help fill these gaps". His conclusion: "Missing, in other words, is a theory of technology - an 'ology' of technology" [3].

This article is an attempt to address this conceptual shortcoming. It focuses on three major deficiencies:

- Technology does not have a single definition.

- Technological activities are not viewed in terms of a central organising framework.

- A generally accepted method for quantifying technological innovation at the national level does not exist.

These deficiencies are briefly outlined, progress is reported, and steps forward are suggested.

\section{DEFINITION OF TECHNOLOGY}

\subsection{Origin of the term}

As far as can be traced, Johann Beckmann [4], writing in 1777, was the first academic formally to use the term 'technology' - or, as it was originally written in German, 'Technologie'. It seems that it came to be used in two contexts: (1) a field of knowledge - the 'science of technical phenomena'; and (2) an innovative force operating in the economy. From this single seed the whole body of technological knowledge in use today took root and sprouted.

The first context was in use for about 100 years. It featured in curricula in universities on the European continent. The second context drew attention to a hereto invisible influence. Economists at the time had to resort to magical metaphors to explain it. One example is the "invisible hand" [5].

In subsequent years, the concept of technology spread to the English-speaking world. Its unique meaning was lost in translation [6]. A pluralistic, diversified view of technology emerged. Today it is estimated that there are more than twenty definitions.

\subsection{Present status of the term}

A companion to the philosophy of technology - published in 2009 - offers a wide-ranging review of the present situation. The Companion is a compilation of the views of about 100 research workers, and is claimed to be "the first comprehensive, authoritative, reference source for this burgeoning and increasingly important field" [7].

In the Companion a chapter is devoted to definition, titled the "Definitions of Technology" [8]. The plural is significant. A review of these definitions is not attempted here. A most disturbing conclusion by the editors of the Companion says it all: "A single definition simply cannot fathom the complexity of technology in its entirety" [7].

This is deeply disturbing. It implies that when engineers, executives, and engaged individuals use the word 'technology', it is not immediately obvious what they are talking about. Speakers have to state explicitly which of the many meanings they intend.

A similar, but more concise, comment on imprecision is offered by Arthur [3], referred to in Chapter 1. He poses the question: What is technology? His response: "The answer, whether we turn to dictionaries or the writings of technology thinkers, is annoyingly unclear" [3]. And there are comments by others in the same vein that are not detailed here. 
It should be recorded that, in the many discussions of definitions, including those mentioned here, Beckmann's [4] root thoughts are not mentioned at all. They seem to have evaporated - a disappearance virtually unnoticed by both academics and practitioners.

\subsection{Suggested definition}

A single definition of technology is needed to redress the current confusing state of affairs. A shared point of departure has to be chosen. Unfortunately, the original definition is not compatible with the conventional pluralistic view.

In the light of recent research, the following formulation is suggested: "Technology is functionality, created by people and expressed in devices, procedures and human skill". This definition has evolved over time after being analysed in theory and used in practice [9].

It contains four important conventions:

- The word 'functionality' implies an ability to execute. The definition therefore refers to the means of execution and not the end. Final creations - such as artistic expressions, literature, and pure scientific insight - are excluded.

- The word 'created' indicates artificiality. To exist, technology has to be made by someone. It does not occur in nature. This definition therefore excludes natural phenomena such as silicon, DNA, and naturally occurring electricity. When these phenomena are deliberately altered to serve as means, the altered states fall within the ambit of technology.

- $\quad$ The word 'people' limits the scope to human creators. Devices, procedures, and skills produced by animals are excluded. This does not mean that the artefacts of animals - such as the termite-gathering sticks of chimpanzees, the nests of birds and wasps, or spider webs - do not constitute some of the most technologically interesting devices on the planet. They are studied as a source of ideas. But they are excluded from the list of items covered by the above definition.

- While human skill is included in the definition, humans themselves are not.

The definition above is offered as a convenient point of departure that has to be examined further. It lays no claim to ultimate acceptability.

\section{ORGANISING FRAMEWORK}

\subsection{Functionality grid}

While many pragmatic classifications of technology have been developed over the years, none have achieved the status of a 'taxonomy'. Taxonomies exist for virtually every developed body of knowledge. Examples include the International Standard Industrial Classification (ISIC) for economics, the periodic table for chemistry, the electromagnetic spectrum for energy, and the families of plants for botany.

While a formal taxonomy for technology could not be found, there is a little-known and ingenious format that could serve as organising framework. It has been termed the functionality grid. It has the advantage of using the notion of functionality - a key concept in the definition of technology. Using this notion, it is possible to think of functionality in nine fundamental categories, formed by three actions and three outcomes.

The three actions are:

- $\quad$ Process

- Transport

- $\quad$ Store

The three outcomes are:

- $\quad$ Matter $(M)$

- $\quad$ Energy (E)

- Information (I)

It is possible to combine these into a nine-cell matrix, as illustrated in Figure 1. 
The original nine-cell matrix was conceived by Ropohl [10] late in the twentieth century. Over the years it has been modified slightly to agree more with the conventions of matrices used in the analyses of engineering systems.

\begin{tabular}{|c|c|c|c|c|}
\hline & & \multicolumn{3}{|c|}{ Outcome } \\
\hline & & $\begin{array}{l}\text { Matter } \\
\text { (M) }\end{array}$ & $\begin{array}{l}\text { Energy } \\
(E)\end{array}$ & $\begin{array}{l}\text { Information } \\
\text { (I) }\end{array}$ \\
\hline \multirow{3}{*}{ Action } & Process & & & \\
\hline & Transport & & & \\
\hline & Store & & & \\
\hline
\end{tabular}

Figure 1: Functionality grid

The functionality grid has five useful characteristics.

- It is profoundly simple.

- It is unique - it is the only example of natural order in the entire world of technological knowledge

- It has a complete array of technological categories

- There are clear family relationships between categories

- It is scaleable - it can be used from the micro to the macro level

Ropohl's matrix [10] had a deep and energising influence on structuring knowledge. While not in popular use, it is attracting increasing attention in the literature. In 2000 it was used to explore the simplification in the organisation of medical technologies [11]; and in 2003 the Engineering Systems Division at MIT used it in a study of the classification of complex systems [12]. It continues to arise in the policy debates of pioneering nations that regard the theory of technology as an essential body of national knowledge [13].

\subsection{National innovation chain}

The functionality grid can also be used to visualise a most useful concept: the national innovation chain. In 2007, Lundvall [14] pointed out that a national system of innovation should be more than an analytical concept: it should be a development tool. The grid can be used in a 'bow tie structure', providing the knot that ties scientific discoveries to various fields of practical application. A bow tie structure has been explained elsewhere [15]. A national innovation chain is illustrated in Figure 2. 


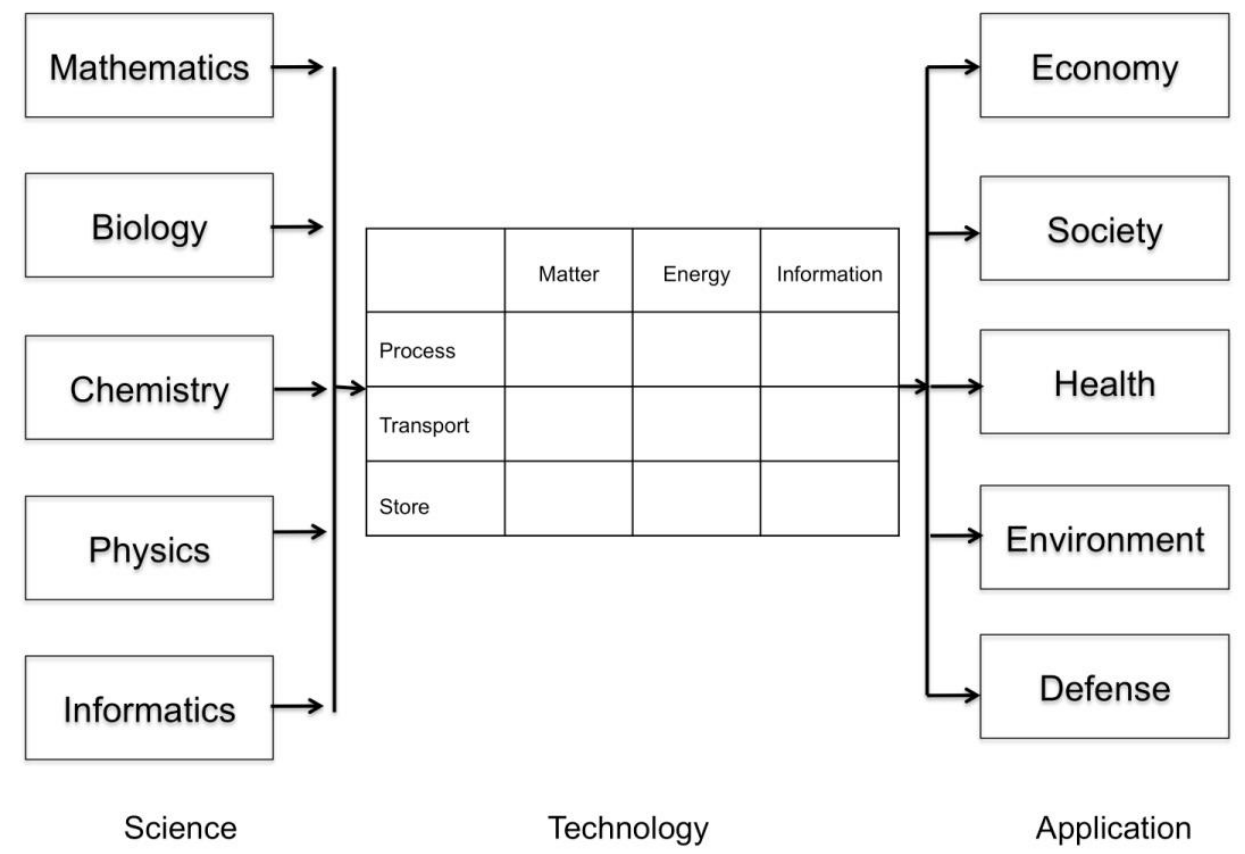

Figure 2: National innovation chain

Presented in this way, the chain has two key directions: (1) from scientific discovery to the state of technology, and (2) from the state of technology to areas of application. (In this figure, the various areas of application have been chosen for their theoretical convenience; there is no fundamental order underpinning the choice.)

The first direction has been described in the literature - but admittedly there have been problems in finding appropriate units [9].

The second direction has been described for two out of the five chosen areas of application - i.e., the economy, and the environment. It has yet to be explored for the remaining three: society, health, and defence [9].

\section{QUANTIFYING INNOVATION}

\subsection{Early endeavours}

Early endeavours to quantify innovation date back to the 1950s and 1960s, when there was no clear language for the technology-application relationship. The problem was referred to in various ways, including expressions such as "the relationship between technological progress and economic growth" and "science, economic growth and government policy" [16]. There were also broader conceptions from the policy sciences, such as described in 'The science of science: A programme and a plea' [17].

According to the Freeman formulation, the quantification of innovation could be seen as a two-stage event:

- $\quad$ Scientific research >>> Enhanced outcomes

According to this formulation, scientific research led directly to enhanced outcomes. Scientific research and technology were regarded as interwoven concepts.

The mid-1950s saw a series of landmark articles aimed at quantifying the impact of technological progress. These included 'Resource and output trends in the United States since 1870' [18], and 'Technical progress and the aggregate production function' [19]. These studies were the first to estimate the magnitude of 
technological progress as a source of overall economic growth. This was as much as 50 per cent, or even more; and they showed how a complex phenomenon could be expressed in terms of a simple computational model.

The aggregate production function approach became the dominant paradigm in studying the impact of technological progress on economic growth. In essence, it depicts economic growth as a function of (1) labour inputs, (2) capital inputs, and (3) total factor productivity (TFP). In this model, the extent of total factor productivity is determined by technological progress, but it is grouped together with other residual influences, such as economies of scale.

According to one version of the aggregate production function, the growth in TFP can be quantified using the following expression:

$$
\Delta \mathrm{Y} / \mathrm{Y}=\mathrm{a} \Delta \mathrm{L} / \mathrm{L}+\mathrm{b} \Delta \mathrm{K} / \mathrm{K}+\Delta \mathrm{T} / \mathrm{T}
$$

where:

$\mathrm{Y}=$ gross domestic product $(\mathrm{GDP})$

$\mathrm{L}=$ labour

$\mathrm{K}=$ capital

$\mathrm{T}=$ total factor productivity (TFP)

$a$ and $b=$ parameters that weigh the contribution of $L$ and $K$

In this model it is possible to find a time series of data for $\mathrm{Y}, \mathrm{L}$, and $\mathrm{K}$, and to infer values for a and $\mathrm{b} . \Delta \mathrm{T} / \mathrm{T}$ is then calculated as a residual. Typically $\Delta T / T$ accounts for between 40 and 60 per cent of $\Delta Y / Y$. TFP is, therefore, an important element in overall economic growth. This work inspired the creative attention of two generations of scholars, policy-makers, and managers, and paved the way for an impressive body of knowledge that continues to grow to this day. These include attempts to disaggregate TFP to yield measures of its various components. This would yield a clear measure of the share of technology.

An example of recent research is 'Raising the speed limit: U.S. economic growth in the information age' [20]. The Advisory Committee on Measuring Innovation in the $21^{\text {st }}$ Century Economy used this study in the formulation of the Committee's final report [21].

However, many scholars have expressed doubts as to whether the aggregate production function approach can be disaggregated far enough. Can we measure the impact of 'technology' on its own, stripped of the other components that make up TFP? In spite of many creative studies, this question remains unanswered. By the mid-1980s, some scholars had come to the conclusion that the "contemporary theory of technical progress seems to have reached a dead end" [22].

\subsection{Recent contributions}

In recent research the original formulation, reflecting Freeman's approach, has been extended to a threestage event. The notion that technology can be depicted separately from science enables a major new insight:

- $\quad$ Scientific research >>> Improved technological capability $>>>$ Enhanced outcomes

This has led to the creation of the national innovation chain, as presented in Section 3.2. Using this format has yielded some success in exploring the link between technology and the economy. It involves the use of functional performance metrics (FPMs), which measure various aspects of change within a given functionality. They are graphed as S-curves [9]. Although different measures can be used to depict different devices, five sets of measures are common to each functionality. It is possible, therefore, to get an overview of all functionalities with 45 common FPMs. Professionals can use this overview to make personal judgements of aggregate technological advance [9].

Building on this notion, recent research has also outlined a procedure for monitoring and anticipating technological advance, termed an 'omega map'. This map consists of a series of anticipated functionality grids reaching into the future and approaching theoretical limits [9]. These anticipated technology grids contribute to technology foresight. 
However, it must be admitted that, as yet, no effective way of measuring the impact of technology at the national economic level has been developed.

\section{FUTURE STEPS}

This chapter outlines a series of possible next steps to contribute to a more unified view of technology.

\subsection{Definition of 'technology'}

As this article is disseminated, the problem of definition will inevitably be part of academic discussion. One aspect that will be different is that Beckmann's first formal definition of technology will become better known in academic circles. Exposure to this history could affect how academics think of a definition. There could be more understanding of the value of a single point of departure.

In addition to this natural debate, it is proposed to approach all contributors to $A$ companion to the philosophy of technology to ask for their comments on an appropriate definition. This group has been selected by informed editors, and would have oversight of the world of technology. Also, the present Companion does not provide guidance on this crucial matter, and the team of contributors may have a sense of the urgency of resolving the imprecision.

\subsection{Organising framework}

Much work has been done on the national innovation chain, but many aspects require more attention.

In Direction 1 - i.e., the link between science and technology, the question of units needs to be resolved.

Also needed is a completion of Direction2 - i.e., a description of the links between technology, society, health, and defence.

An illustration of the practical application of an omega map is also needed. This will be achieved by illustrating the identification of technology landmarks on an accessible website [9].

\subsection{Quantifying innovation}

No methodology has as yet been created to quantify innovation effectively on a national scale. In the past, this question does not seem to have attracted much attention from academics. One exception is Farrell, referred to in the Introduction, whose research has developed in a unique way. He emphasises the value of direct empirical observation [1]. He claims: "The richness of data on simple products makes innovation metrics possible. And when that richness extends over so many of them, connections to GDP become decipherable" [23]. He uses data that is widely available in everyday business use, but not previously collected academically in a coherent way.

His approach involves tools that are applicable to increasing levels of aggregation. Six levels are frequently used: (1) device, (2) establishment, (3) firm, (4) industry, (5) sector, and (6) national economy.

Farrell starts his analysis by looking at technological advance at the device level. He uses S-curves to track technological advance, which reflects functional performance metrics, referred to above. By noting how prices change as technology advances in individual devices and in markets (a combination of levels 2 and 3 ), he quantifies innovation. He then proceeds to the next levels of aggregation "until the connections to GDP become decipherable" [23].

At this stage, details of these calculations cannot be discussed in this article, as they are subject to nondisclosure agreements [24].

What can be said is that, over the years, as the analysis has progressed towards higher levels of aggregation, Farrell has developed the most original and unusual academic constructs. Future work on quantifying the impact of technology at different levels of aggregation will be rewarded by a further elucidation of the Farrell approach.

\section{6} CONCLUSION

This article has its roots in endeavours by organisations to anticipate emerging technologies in order to gain foresight, and to discern strategic opportunities. 
These endeavours have been hampered by inadequacies in the theory of technology. No overarching view is available to augment the conventional pluralistic view.

The article then focuses on three shortcomings in theory: (1) definition, (2) organising framework, and (3) quantification. It reviews these shortcomings, highlights progress, and suggests the next steps.

The article, one hopes, will contribute to simplifying the theory of technology and encouraging technological awareness and wisdom among engineers, executives, educators, economists, and engaged individuals.

\section{ACKNOWLEDGEMENTS}

The comments of George Biltz MD and Chris Farrell PhD are gratefully acknowledged. However, no delegation of responsibility is implied.

\section{REFERENCES}

[1] Farrell, C. 1993. A theory of technological progress. Technological Forecasting and Social Change, 44(2), pp. 161178.

[2] Pearson, G. \& Young, A.T. (eds). 2002. Technically speaking: Why all Americans need to know more about technology. Washington, DC: Committee on Technological Literacy, National Academy of Engineering; National Research Council.

[3] Arthur, W.B. 2009. The nature of technology. New York, NY: Free Press.

[4] Beckmann, J. 1777. Anleitung zur Technologie [Introduction to technology].Göttingen: Vandenhoek.

[5] Smith, A. 1776, 1904. An inquiry into the nature and causes of the wealth of nations, $5^{\text {th }}$ ed. London: Methuen and Company Ltd.

[6] Schatzberg, E. 2006. Technik comes to America: Changing meanings of technology before 1930. Technology and Culture, 47(3), ProQuest, pp. 486-512.

[7] Olsen, J.K.B., Pederson, S.A. \& Hendricks, V.F. 2009. A companion to the philosophy of technology. Chichester: Wiley-Blackwell.

[8] Li-Hua, R. 2009. Definitions of technology. In Olsen, J.K.B., Pederson, S.A. \& Hendricks, V.F. (eds), A companion to the philosophy of technology, pp.18-22. Chichester: Wiley-Blackwell.

[9] Van Wyk, R.J. 2019. Towards technological awareness and wisdom. Available online [Accessed 11 Dec 2020]: https://www.researchgate.net/profile/Rias_Van_Wyk/publication/336409668_191005_-

_Awareness_and_Wisdom/links/5da23e4e45851553ff8c2401/191005-Awareness-and-Wisdom.pdf

[10] Ropohl, G. 1979. Eine systemtheorie der technik. Munich and Vienna: Carl Hanser Verlag.

[11] van Wyk, R. J. 2000. A macro-map of medical technologies: Introductory thoughts. International Journal of Healthcare Technology and Management, 2(1-4), 204-217.Author pp. 204-217.

[12] Magee, C.I. \& DeWeck, O.L. 2002. An attempt at complex system classification. Cambridge, Massachusetts: Massachusetts Institute of Technology.

[13] Compton, V. 2004. Technological knowledge: A developing framework for technology education in New Zealand. Wellington: Ministry of Education.

[14] Lundvall, B. 2007. National innovation systems - Analytical concept and development tool. Industry and Innovation, 14(1), pp. 95-119.

[15] Csete, M. \& Doyle, J. 2004. Bow ties, metabolism and disease. Trends in Biotechnology, 22(9), pp. 446-450.

[16] Freeman, C. 1963. Science, economic growth and government policy. Paris: Organization for Economic Cooperation and Development.

[17] Dedijer, S. 1966. The science of science: A programme and a plea. Minerva, 4(4), pp. 489-504.

[18] Abramovitz, M. 1956. Resource and output trends in the United States since 1870. American Economic Review, 46, pp. 5-23.

[19] Solow, R.M. 1957. Technical change and the aggregate production function. Review of Economics and Statistics, 39, pp. 312-320.

[20] Jorgensen, D. \& Stiroh, K.J. 2000. Raising the speed limit: U.S. economic growth in the information age. Brookings Papers on Economic Activity 1, pp. 125-202.

[21] Advisory Committee on Measuring Innovation in the $21^{\text {st }}$ Century Economy. 2008. Innovation measurement. Washington DC: US Department of Commerce.

[22] Majer, H. 1985. Technology measurement: The functional approach. Technological Forecasting \& Social Change, 27, pp. 335-351.

[23] Farrell, C. 2008. Measuring innovation. Royal Economic Society Newsletter, 142.

[24] Farrell, C. 2018. Innovation in economics: The missing pieces. Chicago: Technology Matters. (Limited circulation. See www.techmatt.com) 